\title{
A Reclamação Como Meio de Impugnação das Decisões das Turmas Recursais dos Juizados Especiais Cíveis
}

\author{
The Complaint as a Means of Challenging the Decisions of the Groups of Appeals of the \\ Special Civil Courts
}

Alexandre Freitas Câmara'

${ }^{1}$ Fundação Getúlio Vargas - FGV, Brasil

\section{Resumo}

\begin{abstract}
Este texto analisa o emprego, cada vez mais disseminado, da reclamação como meio de impugnação das decisões proferidas pelas Turmas Recursais dos Juizados Especiais Cíveis, desde sua origem até o momento atual, em que se verifica um emprego distorcido do instituto, como se a reclamação fosse um verdadeiro recurso.

Palavras-chave: Juizados especiais cíveis; Reclamação; Recurso; Código de processo civil
\end{abstract}

\begin{abstract}
This paper analyses the using, that has become frequent, of Reclamação to attack judgments rendered by the Appeal Courts in the System of Small Claim Courts, since its very beginning to nowadays, when the Reclamação is used as it was a real appeal.
\end{abstract}

Keywords: Small claim courts; Reclamation; Appeal; Civil procedure code.

\section{Introdução}

Este breve ensaio é uma homenagem ao centenário de José Joaquim Calmon de Passos. Calmon foi uma pessoa extremamente importante na minha formação como jurista. Lembro, até hoje, a primeira vez que vi uma palestra dele, no Hotel Glória, no Rio de Janeiro. Fiquei absolutamente chocado ao ver aquele "velhinho" falando aquele monte de coisas que para mim eram, àquela altura, completamente novas. A importância da filosofia para compreender o Direito, a distinção entre texto e norma, a necessidade de se pensar criticamente o ordenamento jurídico, tudo isso era, naquela altura, novo para aquele jovem Alexandre, que estava começando sua carreira no magistério e na advocacia.

Lembro que quando a palestra acabou, todos levantaram e aplaudiram Calmon de pé. Todos menos eu, que fiquei sentado, chocado e emocionado, com os olhos cheios de lágrimas por perceber, naquele momento, que o Direito era muito mais do que a dogmática.

O tempo passou, e a vida nos aproximou. Foram tantos os eventos de que participamos juntos, tantos os encontros em congressos e seminários por todo o Brasil, que nos tornamos amigos. Uma das maiores emoções da minha vida foi assistir a uma palestra que ele deu em um congresso (já nem me lembro mais onde), logo depois da minha exposição, e ele disse que ao me ver lembrava dele cinquenta anos mais novo (e essa é, precisamente, nossa diferença de idade, já que completo cinquenta anos no ano 
de seu centenário). Ali eu tive certeza de que estava no caminho certo, caminho que ainda tento trilhar para ser um processualista digno da tradição de grandes processualistas brasileiros.

Nossa amizade abriu caminho para que eu, em certo momento, o convidasse para escrever um prefácio. E ele o fez, elaborando um belo texto que abre meu livro Juizados Especiais Cíveis Estaduais, Federais e da Fazenda Pública - uma apreciação crítica. E ele começa o prefácio dizendo que meu convite tinha sido uma provocação, porque ele não gostava dos Juizados. Pois devo agora confessar, tantos anos passados, que este foi, exatamente, um dos motivos que me levaram a fazer aquele convite. E se o convite foi uma provocação, o prefácio também é extremamente provocativo.

Conto tudo isso para justificar a escolha deste tema. Voltar a produzir um texto sobre um tema ligado ao sistema processual dos Juizados Especiais é uma forma de me reencontrar com Calmon. Fica, aqui, minha homenagem e a expressa manifestação da minha imensa saudade.

Este artigo enfrenta a questão do uso da reclamação como meio de impugnação das decisões judiciais proferidas por Turmas Recursais dos Juizados Especiais Cíveis. Depois de uma breve consideração sobre a reclamação como demanda autônoma de impugnação de decisões judiciais, descreverei o modo como se começou a usá-la para impugnar decisões proferidas pelas Turmas Recursais dos Juizados Especiais Cíveis. Em seguida, apresentarei o modo como, a partir do CPC/2015, a reclamação realmente pôde ser empregada com este fim, indicando o modo como isso deve acontecer. Na sequência, porém, tratarei da deturpação do sistema causada pela Resolução n. 03/2016, do STJ, que causou a atual situação, que tem gerado sérios problemas sistêmicos. Ao final, apontarei algumas considerações conclusivas.

\section{A reclamação como meio de impugnação das decisões judiciais}

A reclamação é um processo de competência originária de tribunais, ${ }^{1}$ que pode ter por finalidade a preservação de sua competência ou a garantia da autoridade de suas decisões. Prevista na Constituição da República (e, por isso, tradicionalmente chamada de reclamação constitucional), ali se afirma seu cabimento, perante o STF (art. 102, I, 1, e art. 103-A, § 3ㅜ) e perante o STJ (art. 105, I, f). Pois o CPC ampliou o cabimento da reclamação, que passa a poder ser ajuizada perante qualquer tribunal (art. 988, $\S 1^{1}$, primeira parte).

Estabelece a lei processual (art. 988, I a IV) os casos de cabimento da reclamação. O primeiro deles, nos mesmos termos das disposições constitucionais, é o da reclamação cujo objeto é "preservar a competência do tribunal" (art. 988, I). Pense-se, por exemplo, no caso em que que o juízo de primeiro grau profere decisão de inadmissão de apelação. É que, por força do disposto no art. 1.010, $\S 3^{\circ}$, não é de competência do juízo de primeira instância exercer juízo de admissibilidade da apelação. Tal exame cabe, originariamente, ao tribunal de segundo grau. Assim, decisão do juízo de primeira instância que declare inad missível a apelação é ato de usurpação de competência do tribunal de segundo grau. Ocorre que tal decisão, de natureza interlocutória, não é impugnável por agravo de instrumento (até porque não faria mesmo sentido a lei processual prever recurso contra uma decisão que ela expressamente diz que não deve ser proferida), motivo pelo qual a reclamação será, na hipótese, a única via processual adequada para impugnar-se aquele ato jurisdicional praticado por órgão desprovido de competência para praticá-lo.

Também se admite reclamação, perante qualquer tribunal, para garantir a autoridade das suas decisões (art. 988, II). Imagine-se a seguinte hipótese: juízo de primeira instância indefere inversão do ônus da prova requerida pelo autor. Desta decisão se interpõe agravo de instrumento (art. 1.015, XI), que vem a ser provido, determinando o tribunal uma nova distribuição dos ônus probatórios. O juízo de primeiro grau, então, emite pronunciamento em que comunica às partes que julgará a causa sem a inversão do ônus da prova, por entender não ser o caso de invertê-lo. Este pronunciamento, como parece claro, desrespeita a autoridade da decisão do tribunal, e pode ser impugnado por via de reclamação.

1 HARTMANN, Guilherme Kronemberg. Reclamação no Âmbito do Controle da Observância de Precedentes Judiciais Vinculantes. Revista da EMERJ, v. 21, n. 1, 2019, pág. 157. 
É fundamental perceber, porém, que a reclamação só é cabível com base neste permissivo legal e constitucional quando a decisão cuja autoridade se busca preservar tenha sido proferida no mesmo processo em que se praticou o ato que a descumpre. ${ }^{2}$ Este é entendimento antigo e consolidado na jurisprudência do Supremo Tribunal Federal, como se poder ver pelo seguinte acórdão:

AGRAVO REGIMENTAL EM RECLAMAÇÃO. IMPUGNAÇÃO DE DECISÃO QUE DETERMINA, LIMINARMENTE, O ARQUIVAMENTO DE RECLAMAÇÃO COM DUPLO FUNDAMENTO: FALTA DE DOCUMENTOS ESSENCIAIS E DESCABIMENTO DE RECLAMAÇÃO. 1. Agravo regimental que insiste nas questões de mérito do pedido reclamatório. Na petição de agravo devem ser impugnados tão-somente os fundamentos da decisão agravada, pois, caso contrário, ocorre preclusão das questões processuais decididas. 2. Só cabe reclamação, em regra, para preservar a autoridade das decisões do Tribunal tomadas no mesmo processo. A reclamação não se destina, genericamente, a uniformizar a jurisprudência do Tribunal e, assim, garantir a autoridade de decisões proferidas em outros processos. 3. Agravo regimental a que se nega provimento. (Rcl 646 AgR, Relator(a): Min. MAURÍCIO CORRÊA, Tribunal Pleno, julgado em 06/05/1999, DJ 11-06-1999 PP-00015 EMENT VOL-01954-01 PP-00011)

Outra hipótese prevista em lei como ensejadora do cabimento dessa demanda autônoma é o da reclamação destinada a garantir a observância de enunciado de súmula vinculante ou de decisão proferida pelo STF em controle concentrado de constitucionalidade (art. 988, III, na redação da Lei no 13.256/2016). Trata-se de hipótese em que a reclamação é empregada como mecanismo de preservação da autoridade de padrões decisórios dotados de eficácia vinculante. Afinal, as decisões proferidas pelo STF no exercício do controle direto de constitucionalidade têm eficácia vinculante e erga omnes (art. 102, § 2º , da Constituição da República). Assim, qualquer decisão judicial que venha a ser proferida, em qualquer processo, e que desconsidere o quanto decidido pelo STF em processo de controle direto de constitucionalidade, desrespeita a eficácia vinculante daquela decisão e é impugnável por meio de reclamação. $\mathrm{O}$ mesmo se diga em relação às decisões que violem enunciado de súmula vinculante, hipótese em que o cabimento da reclamação já está expressamente previsto na Constituição da República (art. 103-A, $§ 3^{\circ}$ ).

Outro caso, expressamente previsto, de cabimento da reclamação é a da que tem por objeto "garantir a observância de acórdão proferido em julgamento de incidente de resolução de demandas repetitivas ou de incidente de assunção de competência” (art. 988, IV, na redação da Lei n 13.256/2016). Tem-se, aqui, situação análoga à do inciso anterior, já que também neste caso a reclamação busca assegurar o respeito à eficácia vinculante de padrões decisórios anteriormente estabelecidos e que são de observância obrigatória.

Não é por outra razão que, por força do disposto no art. 988, § 5º II, do CPC, também se deve admitir reclamação contra decisão que não observa tese firmada em recurso extraordinário cujo mérito tenha sido julgado ou recurso especial repetitivo. Nesse caso específico de reclamação, porém, em que o ato impugnado é decisão que contraria precedente fixado em recurso extraordinário (repetitivo ou não, sendo certo que o texto normativo fala em "recurso extraordinário com repercussão geral reconhecida", mas sendo a repercussão geral da questão constitucional um requisito de admissibilidade, não há julgamento de mérito em recurso extraordinário sem que se tenha reconhecido a repercussão geral) ou em recurso especial repetitivo, só se admite o emprego desta via processual após o esgotamento das

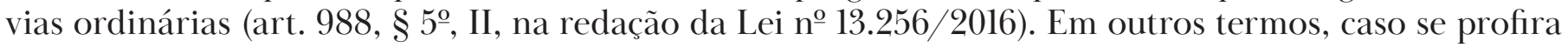
decisão que contrarie algum desses precedentes, será preciso primeiro exaurir as instâncias ordinárias (com a interposição de todos os recursos aí admissíveis, como a apelação, por exemplo) e, depois, caso mantido o julgado contrário ao padrão decisório, aí sim impetrar-se a reclamação.

Vale aqui, porém, uma observação relevante. O Superior Tribunal de Justiça proferiu decisão no sentido de que não se pode empregar a reclamação como mecanismo destinado a assegurar a observância dos precedentes firmados no julgamento de recursos especiais repetitivos. Confira-se a ementa do acórdão:

2 Em sentido diverso, porém, ABREU, Vinicius Caldas Gama e. Reclamação Constitucional. Dissertação de Mestrado. São Paulo: PUC-SP. 2018, pág. 65. 
RECLAMAÇÃO. RECURSO ESPECIAL AO QUAL O TRIBUNAL DE ORIGEM NEGOU SEGUIMENTO, COM FUNDAMENTO NA CONFORMIDADE ENTRE O ACÓRDÃO RECORRIDO E A ORIENTAÇÃO FIRMADA PELO STJ EM RECURSO ESPECIAL REPETITIVO (RESP 1.301.989/RS - TEMA 658). INTERPOSIÇÃO DE AGRAVO INTERNO NO TRIBUNAL LOCAL. DESPROVIMENTO. RECLAMAÇÃO QUE SUSTENTA A INDEVIDA APLICAÇÃO DA TESE, POR SE TRATAR DE HIPÓTESE FÁTICA DISTINTA. DESCABIMENTO. PETIÇÃO INICIAL. INDEFERIMENTO. EXTINÇÃO DO PROCESSO SEM RESOLUÇÃO DO MÉRITO.

1. Cuida-se de reclamação ajuizada contra acórdão do TJ/SP que, em sede de agravo interno, manteve a decisão que negou seguimento ao recurso especial interposto pelos reclamantes, em razão da conformidade do acórdão recorrido com o entendimento firmado pelo STJ no REsp 1.301.989/RS, julgado sob o regime dos recursos especiais repetitivos (Tema 658).

2. Em sua redação original, o art. 988, IV, do CPC/2015 previa o cabimento de reclamação para garantir a observância de precedente proferido em julgamento de "casos repetitivos", os quais, conforme o disposto no art. 928 do Código, abrangem o incidente de resolução de demandas repetitivas (IRDR) e os recursos especial e extraordinário repetitivos.

3. Todavia, ainda no período de vacatio legis do CPC/15, o art. 988, IV, foi modificado pela Lei 13.256/2016: a anterior previsão de reclamação para garantir a observância de precedente oriundo de "casos repetitivos" foi excluída, passando a constar, nas hipóteses de cabimento, apenas o precedente oriundo de IRDR, que é espécie daquele.

4. Houve, portanto, a supressão do cabimento da reclamação para a observância de acórdão proferido em recursos especial e extraordinário repetitivos, em que pese a mesma Lei 13.256/2016, paradoxalmente, tenha acrescentado um pressuposto de admissibilidade - consistente no esgotamento das instâncias ordinárias - à hipótese que acabara de excluir.

5. Sob um aspecto topológico, à luz do disposto no art. 11 da LC 95/98, não há coerência e lógica em se afirmar que o parágrafo $5^{\circ}$, II, do art. 988 do CPC, com a redação dada pela Lei 13.256/2016, veicularia uma nova hipótese de cabimento da reclamação. Estas hipóteses foram elencadas pelos incisos do caput, sendo que, por outro lado, o parágrafo se inicia, ele próprio, anunciando que trataria de situações de inadmissibilidade da reclamação.

6. De outro turno, a investigação do contexto jurídico-político em que editada a Lei 13.256/2016 revela que, dentre outras questões, a norma efetivamente visou ao fim da reclamação dirigida ao STJ e ao STF para o controle da aplicação dos acórdãos sobre questões repetitivas, tratando-se de opção de política judiciária para desafogar os trabalhos nas Cortes de superposição.

7. Outrossim, a admissão da reclamação na hipótese em comento atenta contra a finalidade da instituição do regime dos recursos especiais repetitivos, que surgiu como mecanismo de racionalização da prestação jurisdicional do STJ, perante o fenômeno social da massificação dos litígios.

8. Nesse regime, o STJ se desincumbe de seu múnus constitucional definindo, por uma vez, mediante julgamento por amostragem, a interpretação da Lei federal que deve ser obrigatoriamente observada pelas instâncias ordinárias. Uma vez uniformizado o direito, é dos juízes e Tribunais locais a incumbência de aplicação individualizada da tese jurídica em cada caso concreto.

9. Em tal sistemática, a aplicação em concreto do precedente não está imune à revisão, que se dá na via recursal ordinária, até eventualmente culminar no julgamento, no âmbito do Tribunal local, do agravo interno de que trata o art. $1.030, \S 2^{\circ}$, do CPC/ 15 .

10. Petição inicial da reclamação indeferida, com a extinção do processo sem resolução do mérito.

(Rcl 36.476/SP, Rel. Ministra NANCY ANDRIGHI, CORTE ESPECIAL, julgado em 05/02/2020, DJe 06/03/2020)

Este entendimento, que vem sendo reiterado pelo Superior Tribunal de Justiça, está triplamente equivocado. Primeiro, por contrariar frontalmente o disposto no texto da lei, que evidentemente estabelece que a reclamação nesse caso não é cabível senão depois de esgotadas as instâncias ordinárias, o que mostra que, perdoe-se a obviedade, depois do esgotamento das instâncias ordinárias a reclamação passa a ser admissível. Segundo, porque a decisão parte de uma premissa que quase se pode qualificar como ingênua: a de que os Tribunais sempre seguirão os entendimentos consolidados pelo STJ no julgamento de recursos repetitivos. Ora, se isso fosse verdade, não haveria qualquer razão para que a reclamação estivesse prevista no sistema. Terceiro, porque na prática esse entendimento acaba por aniquilar a eficácia vinculante desses acórdãos do STJ. Bastará que o tribunal de segunda instância não 
o observe e a parte não poderá valer-se da reclamação. E muito provavelmente não conseguirá chegar ao STJ por meio de recurso especial, pois o Tribunal já terá se manifestado sobre aquela matéria, razão pela qual o recurso especial provavelmente não será admitido. Isso sem contar que, se eventualmente o recurso chegar ao STJ, a parte correrá o sério risco de esbarrar no enunciado 7 da súmula do STJ e na afirmação de ser inadmissível o recurso especial por que a análise da aplicabilidade ao caso do precedente firmado no julgamento do recurso repetitivo demandaria reexame de matéria fática, o que não pode acontecer em sede de recurso especial.

Aliás, vale a pena destacar que o STF tem dado correta interpretação à hipótese, como se pode ver do seguinte aresto:

RECLAMAÇÃO - ACÓRDÃO - REPERCUSSÃO GERAL - OBSERVÂNCIA - INSTÂNCIAS ORDINÁRIAS ESGOTAMENTO - AUSÊNCIA. A parte final do artigo 988, $\S 5^{\circ}$, inciso II, do Código de Processo Civil revela estar condicionada a admissibilidade da reclamação, visando a observância de acórdão alusivo a extraordinário submetido ao regime da repercussão geral, ao esgotamento prévio das instâncias ordinárias. RECLAMAÇÃO - OBJETO. A reclamação pressupõe usurpação da competência do Supremo ou desrespeito a decisão por si proferida, sendo imprópria a utilização da medida como sucedâneo recursal. (Rcl 37282 AgR, Relator(a): Min. MARCO AURÉLIO, Primeira Turma, julgado em 11/05/2020, PROCESSO ELETRÔNICO DJe-127 DIVULG 2105-2020 PUBLIC 22-05-2020)

Estes são, então, os casos de cabimento da reclamação, estabelecidos pelo CPC vigente. É preciso, porém, ver como isso se aplica quando a decisão que se pretende impugnar tenha sido proferida por Turma Recursal dos Juizados Especiais Cíveis.

\section{A origem do cabimento da reclamação como meio de impugnação de decisões proferidas por Turmas Recursais dos Juizados Especiais Cíveis}

O Supremo Tribunal Federal, ao apreciar embargos de declaração no RE 571572/BA, rel. Min. Ellen Gracie, estabeleceu o cabimento de reclamação contra decisões proferidas por Turmas Recursais de Juizados Especiais que estivessem em conflito com a jurisprudência do Superior Tribunal de Justiça. Tal acórdão está assim ementado:

EMBARGOS DE DECLARAÇÃO. RECURSO EXTRAORDINÁRIO. AUSÊNCIA DE OMISSÃO NO ACÓRDÃO EMBARGADO.JURISPRUDÊNCIA DOSUPERIORTRIBUNALDEJUSTIÇA. APLICAÇÃOÀS CONTROVÉRSIAS SUBMETIDAS AOS JUIZADOS ESPECIAIS ESTADUAIS. RECLAMAÇÃO PARA O SUPERIOR TRIBUNAL DE JUSTIÇA. CABIMENTO EXCEPCIONAL ENQUANTO NÃO CRIADO, POR LEI FEDERAL, O ÓRGÃO UNIFORMIZADOR. 1. No julgamento do recurso extraordinário interposto pela embargante, o Plenário desta Suprema Corte apreciou satisfatoriamente os pontos por ela questionados, tendo concluído: que constitui questão infraconstitucional a discriminação dos pulsos telefônicos excedentes nas contas telefônicas; que compete à Justiça Estadual a sua apreciação; e que é possível o julgamento da referida matéria no âmbito dos juizados em virtude da ausência de complexidade probatória. Não há, assim, qualquer omissão a ser sanada. 2. Quanto ao pedido de aplicação da jurisprudência do Superior Tribunal de Justiça, observe-se que aquela egrégia Corte foi incumbida pela Carta Magna da missão de uniformizar a interpretação da legislação infraconstitucional, embora seja inadmissível a interposição de recurso especial contra as decisões proferidas pelas turmas recursais dos juizados especiais. 3. No âmbito federal, a Lei 10.259/2001 criou a Turma de Uniformização da Jurisprudência, que pode ser acionada quando a decisão da turma recursal contrariar a jurisprudência do STJ. É possível, ainda, a provocação dessa Corte Superior após o julgamento da matéria pela citada Turma de Uniformização. 4. Inexistência de órgão uniformizador no âmbito dos juizados estaduais, circunstância que inviabiliza a aplicação da jurisprudência do STJ. Risco de manutenção de decisões divergentes quanto à interpretação da legislação federal, gerando insegurança jurídica e uma prestação jurisdicional incompleta, em decorrência da inexistência de outro meio eficaz para resolvê-la. 5. Embargos declaratórios acolhidos apenas para declarar o cabimento, em caráter excepcional, da reclamação prevista no art. 105, I, f, da Constituição Federal, para fazer prevalecer, até a criação da turma de 
uniformização dos juizados especiais estaduais, a jurisprudência do Superior Tribunal de Justiça na interpretação da legislação infraconstitucional (RE 571572 ED, Rel. Min. Ellen Gracie, Tribunal Pleno, j. em 26/08/2009).

Em seu voto, afirmou a eminente relatora que por "não exist[ir] previsão legal de órgão uniformizador da interpretação da legislação federal para os juizados especiais estaduais, [pode], em tese, ocorrer a perpetuação de decisões divergentes da jurisprudência do STJ". Entendeu, então, a relatora que "enquanto não for criada a turma de uniformização para os juizados especiais estaduais, [pode-se] ter a manutenção de decisões divergentes a respeito da interpretação da legislação infraconstitucional federal, [situação que], além de provocar insegurança jurídica, acaba provocando uma prestação jurisdicional incompleta, em decorrência da inexistência de outro meio eficaz para resolvê-la”.

Pois por tal fundamento, afirmou a relatora, em seu voto, que "até que seja criado o órgão que possa estender e fazer prevalecer a aplicação da jurisprudência do STJ, em razão de sua função constitucional, da segurança jurídica e da devida prestação jurisdicional, a lógica da organização do sistema judiciário nacional recomenda que se dê à reclamação prevista no art. 105, I, f, da CF amplitude suficiente à solução do impasse". E concluiu a relatora no sentido de que "[d]iante da inexistência de outro órgão que possa fazê-lo, o próprio Superior Tribunal de Justiça afastará a divergência com a sua jurisprudência, quando a decisão vier a ser proferida no âmbito dos juizados especiais estaduais".

Como se vê pelos fundamentos determinantes daquele acórdão, aqui apontados, a previsão do cabimento da reclamação para o STJ se deu em razão de ser do Tribunal Superior a missão constitucional de uniformizar a interpretação do direito federal infraconstitucional. E como consequência dessa decisão veio a ser aprovada a Resolução no 12/2009, que dispôs "sobre o processamento, no Superior Tribunal de Justiça, das reclamações destinadas a dirimir divergência entre acórdão prolatado por turma recursal estadual e a jurisprudência [da] Corte”. Aliás, vale aqui recordar que expressamente consta do preâmbulo daquela resolução que a mesma foi tomada "considerando a decisão do Pleno do Supremo Tribunal Federal nos EDcl no RE 571.572-8/BA".

Correta ou não a decisão do STF (e a mim sempre pareceu incorreta, por ter transformado a reclamação num "recurso especial disfarçado", sendo certo que pelo ordenamento constitucional vigente não se admite recurso especial contra decisão de Turma Recursal, e o próprio STF reconhece, em seu acórdão citado, que a Constituição da República não previu o recurso especial e que o seu entendimento deveria ser adotado em razão de uma suposta "omissão" constitucional, e que seria necessária uma emenda à Constituição para que se previsse expressamente um mecanismo de controle das decisões das Turmas Recursais), fato é que o Supremo Tribunal estabeleceu que ao Superior Tribunal de Justiça caberia o julgamento dessas reclamações. Mas aí, veio o CPC de 2015, e tudo mudou.

\section{4. $\mathrm{O} \mathrm{CPC/2015} \mathrm{e} \mathrm{a} \mathrm{reclamação} \mathrm{contra} \mathrm{decisões} \mathrm{proferidas} \mathrm{pelas} \mathrm{Turmas} \mathrm{Recursais} \mathrm{dos}$ Juizados Especiais Cíveis.}

Aprovado o CPC/2015, seu texto original estabelecia, no art. 988, IV, o cabimento de reclamação da parte interessada ou do Ministério Público para "garantir a observância de enunciado de súmula vinculante e de precedente proferido em julgamento de casos repetitivos ou em incidente de assunção de competência”. Sobre esta redação, manifestou-se Leonardo Carneiro da Cunha, afirmando que o CPC/2015 seria capaz de produzir uma revogação tácita da Resolução no 12/2009 do STJ. Confira-se:

\footnotetext{
"Com o advento do CPC de 2015, a Resolução n. 12/2009-STJ está revogada. No âmbito dos Juizados Especiais Cíveis, caberá reclamação ao STJ para garantir a autoridade de suas decisões. E, como já vinha sendo interpretado pelo STJ, o termo "autoridade de suas decisões" abrange enunciado de sua súmula de jurisprudência e casos de decisão judicial teratogênica. Ademais, segundo dispõe o art. 988, IV, do CPC, caberá reclamação ao STJ, no âmbito dos Juizados Especiais Cíveis, para garantir a observância de precedente proferido em julgamento de casos repetitivos ou em incidente de assunção de competência. Assim, firmado precedente em recurso especial repetitivo, a tese jurídica será aplicada a todos os casos, inclusive naqueles em curso em Juizados Especiais Cíveis.
} 
De igual modo, firmado precedente em incidente de assunção de competência no STJ, todos os juízos devem seguir a orientação, inclusive os dos Juizados Especiais Cíveis. Não cumprida a orientação, caberá reclamação.”

É certo, porém, que aquela redação do dispositivo do CPC/2015 jamais chegou a vigorar. Dias antes do término do prazo de vacância do novo Código de Processo Civil foi editada a Lei no 13.256/2016, que modificou o texto normativo, passando o art. 988, IV, a prever o cabimento da reclamação para "garantir a observância de acórdão proferido em julgamento de incidente de resolução de demandas repetitivas ou de incidente de assunção de competência”.

Daí não resulta, porém, ser absolutamente incabível a reclamação quando há violação de tese fixada em recurso especial repetitivo. É que nesse caso a reclamação só é admissível depois de esgotadas todas as instâncias ordinárias (art. 988, § 5oㅡ, II). Ao comentar este dispositivo, afirma Lenio Streck:

"Para ser direto: a reclamação é admitida para garantir a observância de acórdãos proferidos em julgamento
de IRDR e também para assegurar a observância de acórdãos proferidos em julgamentos decorrentes de outras
técnicas de julgamentos repetitivos (REsp repetitivo e RE repetitivo), nessa última hipótese somente em casos nos
quais couber recurso especial e recurso extraordinário. Esgotadas as instâncias ordinárias, a um só tempo será
possível promover ação de reclamação e interpor recursos excepcionais. Mecanismos vinculatórios [podem] ser
sujeitos à sindicância constitucional."

A reclamação é, pois, cabível por força de lei como mecanismo de impugnação de pronunciamento judicial (inclusive oriundo de Turma Recursal de Juizados Especiais) que contrariam decisão tomada em sede de recurso especial repetitivo, como no caso ora em exame. Ocorre que a competência para conhecer dessa reclamação, como não poderia deixar de ser, é do Superior Tribunal de Justiça, o que resulta do disposto no $\S 1^{\circ}$ do art. 988 do $\mathrm{CPC} / 2015$ :

$\S 1^{\circ}$. A reclamação pode ser proposta perante qualquer tribunal, e seu julgamento compete ao órgão jurisdicional cuja competência se busca preservar ou cuja autoridade se pretenda garantir.

É, pois, do Superior Tribunal de Justiça essa competência. E nem poderia ser diferente, já que nos termos do precedente anteriormente mencionado do Supremo Tribunal Federal, essa reclamação é o instituto processual previsto no art. 105, I, f, da Constituição da República. Mas o Superior Tribunal de Justiça não entendeu assim. E editou resolução sobre o tema.

\section{A Resolução 03/2016 do STJ}

Não obstante isso tudo isso que até aqui se expôs, porém, o Superior Tribunal de Justiça revogou expressamente sua Resolução nº 12/2009 e a substituiu pela Resolução no 3/2016, que afirma a competência das Seções Especializadas ou Câmaras Reunidas dos Tribunais de Justiça para delas conhecer.

O ato do STJ, com todas as vênias devidas àquele Tribunal Superior, não só contraria expressamente o que o STF decidiu no já mencionado julgamento dos Embargos de Declaração no RE 571572/BA, mas também um firme e consolidado entendimento jurisprudencial do Supremo Tribunal Federal acerca da impossibilidade de ampliação das competências dos Tribunais por meio de atos normativos infraconstitucionais. Basta ver o que decidiu o STF no julgamento da ADI 2797/2/DF, da relatoria do Min. Sepúlveda Pertence, assim ementado:

I. ADIn: legitimidade ativa: "entidade de classe de âmbito nacional” (art. 103, IX, CF): Associação Nacional dos Membros do Ministério Público - CONAMP 1. Ao julgar, a ADIn 3153-AgR, 12.08.04, Pertence, Inf STF 356, o

3 CUNHA, Leonardo Carneiro da. Novo CPC: Reclamação contra decisões em Juizados Especiais Civeis. Revogação da Resolução 12/2009-STJ. Disponível in http://www.leonardocarneirodacunha.com.br/opiniao/opiniao-61-novo-cpcreclamacao-contra-decisoes-em-juizados-especiais-civeis-revogacao-da-resolucao-122009-stj/, acesso em 03/10/2016.

4 STRECK, Lenio Luiz. Comentário ao art. 988. In: STRECK, Lenio Luiz; NUNES, Dierle; CUNHA, Leonardo Carneiro da (org.); FREIRE, Alexandre (coord.). Comentários ao Código de Processo Civil. São Paulo: Saraiva, 2016, pág. 1.305. 
plenário do Supremo Tribunal abandonou o entendimento que excluía as entidades de classe de segundo grau - as chamadas "associações de associações" - do rol dos legitimados à ação direta. 2. De qualquer sorte, no novo estatuto da CONAMP - agora Associação Nacional dos Membros do Ministério Público - a qualidade de "associados efetivos" ficou adstrita às pessoas físicas integrantes da categoria, - o que basta a satisfazer a jurisprudência restritiva-, ainda que o estatuto reserve às associações afiliadas papel relevante na gestão da entidade nacional. II. ADIn: pertinência temática. Presença da relação de pertinência temática entre a finalidade institucional das duas entidades requerentes e os dispositivos legais impugnados: as normas legais questionadas se refletem na distribuição vertical de competência funcional entre os órgãos do Poder Judiciário - e, em consequência, entre os do Ministério Público. III. Foro especial por prerrogativa de função: extensão, no tempo, ao momento posterior à cessação da investidura na função dele determinante. Súmula 394/STF (cancelamento pelo Supremo Tribunal Federal). Lei 10.628/2002, que acrescentou os $\$ \S 1^{\mathrm{o}}$ e $2^{\mathrm{o}}$ ao artigo 84 do C. Processo Penal: pretensão inadmissível de interpretação autêntica da Constituição por lei ordinária e usurpação da competência do Supremo Tribunal para interpretar a Constituição: inconstitucionalidade declarada. 1. O novo $\S 1^{\text {o }}$ do art. 84 CPrPen constitui evidente reação legislativa ao cancelamento da Súmula 394 por decisão tomada pelo Supremo Tribunal no Inq 687-QO, 25.8.97, rel. o em. Ministro Sydney Sanches (RTJ 179/912), cujos fundamentos a lei nova contraria inequivocamente. 2. Tanto a Súmula 394, como a decisão do Supremo Tribunal, que a cancelou, derivaram de interpretação direta e exclusiva da Constituição Federal. 3. Não pode a lei ordinária pretender impor, como seu objeto imediato, uma interpretação da Constituição: a questão é de inconstitucionalidade formal, ínsita a toda norma de gradação inferior que se proponha a ditar interpretação da norma de hierarquia superior. 4. Quando, ao vício de inconstitucionalidade formal, a lei interpretativa da Constituição acresça o de opor-se ao entendimento da jurisprudência constitucional do Supremo Tribunal - guarda da Constituição -, às razões dogmáticas acentuadas se impõem ao Tribunal razões de alta política institucional para repelir a usurpação pelo legislador de sua missão de intérprete final da Lei Fundamental: admitir pudesse a lei ordinária inverter a leitura pelo Supremo Tribunal da Constituição seria dizer que a interpretação constitucional da Corte estaria sujeita ao referendo do legislador, ou seja, que a Constituição - como entendida pelo órgão que ela própria erigiu em guarda da sua supremacia -, só constituiria o correto entendimento da Lei Suprema na medida da inteligência que lhe desse outro órgão constituído, o legislador ordinário, ao contrário, submetido aos seus ditames. 5. Inconstitucionalidade do $§ 1^{\circ}$ do art. 84 C.Pr.Penal, acrescido pela lei questionada e, por arrastamento, da regra final do $§ 2^{\circ}$ do mesmo artigo, que manda estender a regra à ação de improbidade administrativa. IV. Ação de improbidade administrativa: extensão da competência especial por prerrogativa de função estabelecida para o processo penal condenatório contra o mesmo dignitário ( $\$ 2^{\circ}$ do art. 84 do C Pr Penal introduzido pela L. 10.628/2002): declaração, por lei, de competência originária não prevista na Constituição: inconstitucionalidade. 1. No plano federal, as hipóteses de competência cível ou criminal dos tribunais da União são as previstas na Constituição da República ou dela implicitamente decorrentes, salvo quando esta mesma remeta à lei a sua fixação. 2. Essa exclusividade constitucional da fonte das competências dos tribunais federais resulta, de logo, de ser a Justiça da União especial em relação às dos Estados, detentores de toda a jurisdição residual. 3. Acresce que a competência originária dos Tribunais é, por definição, derrogação da competência ordinária dos juízos de primeiro grau, do que decorre que, demarcada a última pela Constituição, só a própria Constituição a pode excetuar. 4. Como mera explicitação de competências originárias implícitas na Lei Fundamental, à disposição legal em causa seriam oponíveis as razões já aventadas contra a pretensão de imposição por lei ordinária de uma dada interpretação constitucional. 5. De outro lado, pretende a lei questionada equiparar a ação de improbidade administrativa, de natureza civil (CF, art. $37, \S 4^{\circ}$ ), à ação penal contra os mais altos dignitários da República, para o fim de estabelecer competência originária do Supremo Tribunal, em relação à qual a jurisprudência do Tribunal sempre estabeleceu nítida distinção entre as duas espécies. 6. Quanto aos Tribunais locais, a Constituição Federal -salvo as hipóteses dos seus arts. 29, X e 96, III -, reservou explicitamente às Constituições dos Estados-membros a definição da competência dos seus tribunais, o que afasta a possibilidade de ser ela alterada por lei federal ordinária. V. Ação de improbidade administrativa e competência constitucional para o julgamento dos crimes de responsabilidade. 1. O eventual acolhimento da tese de que a competência constitucional para julgar os crimes de responsabilidade haveria de estender-se ao processo e julgamento da ação de improbidade, agitada na Rcl 2138, ora pendente de julgamento no Supremo Tribunal, não prejudica nem é prejudicada pela inconstitucionalidade do novo $§ 2^{o}$ do art. 84 do C.Pr.Penal. 2. A competência originária dos tribunais para julgar crimes de responsabilidade é bem mais restrita que a de julgar autoridades por crimes comuns: afora o caso dos chefes do Poder Executivo - cujo impeachment é da competência dos órgãos políticos - a cogitada competência dos tribunais não alcançaria, sequer por integração analógica, os membros 
do Congresso Nacional e das outras casas legislativas, aos quais, segundo a Constituição, não se pode atribuir a prática de crimes de responsabilidade. 3. Por outro lado, ao contrário do que sucede com os crimes comuns, a regra é que cessa a imputabilidade por crimes de responsabilidade com o termo da investidura do dignitário acusado (ADI 2797, Rel. Min. Sepúlveda Pertence, Tribunal Pleno, j. em 15/09/2005).

No voto condutor do acórdão assim se expressou o eminente relator:

"[Q]uanto aos tribunais locais, afora o disposto nos seus arts. 29, X e 96, III, a Constituição Federal reservou explicitamente às constituições dos Estados-membros a definição da competência aos seus tribunais, o que afasta, por si só, que possa ela ser alterada por lei federal ordinária”.

O eminente relator apoiou-se no art. 125, $§ 11^{\circ}$, da Constituição da República:

$\S 1^{\circ}$. A competência dos tribunais será definida na Constituição do Estado, sendo a lei de organização judiciária de iniciativa do Tribunal de Justiça.

Ora, se é impossível ampliar por lei federal ordinária a competência dos Tribunais de Justiça, $a$ fortiori também é vedada tal ampliação por resolução do Superior Tribunal de Justiça. ${ }^{5}$

E nem se diga que o CPC/2015 teria ampliado competências deste Tribunal de Justiça ao prever que aqui seriam julgadas as reclamações para preservar a autoridade das decisões desta Corte Estadual. É que tal competência deriva diretamente do princípio da simetria e da teoria dos poderes implícitos.

Sobre a incidência, na hipótese, do princípio da simetria, vale recordar a lição de Fredie Didier Júnior, para quem "[a] adoção da reclamação constitucional no âmbito dos tribunais de justiça, segundo entendimento firmado pelo STF, decorre do princípio da simetria dos entes federados e, bem ainda, do princípio da efetividade das decisões judiciais." ${ }^{6}$

De outro lado, o reconhecimento do poder do Tribunal de Justiça exarar decisões dotadas de eficácia vinculante faz com que, ao menos implicitamente, seja preciso reconhecer sua competência para conhecer de mecanismos destinados a preservar a autoridade de suas próprias decisões.

A competência do Tribunal de Justiça para conhecer de reclamação, porém, tem de ser limitada à preservação da autoridade das decisões que dele são emanadas. Não há sentido em se atribuir a um tribunal estadual competência para conhecer de reclamação destinada a preservar autoridade de decisão de outra Corte, ainda que se trate do Superior Tribunal de Justiça.

Isso levou a que se suscitasse conflito de competência (entre o TJRJ e o STJ), a fim de que o Supremo Tribunal Federal definisse a quem incumbiria julgar esse tipo de reclamação.

\section{O atual "estado da arte" sobre o tema}

O conflito de competência a que acabo de fazer referência foi distribuído ao STF sob o n. 7970/ RJ, e sua relatoria coube ao eminente Min. Celso de Mello. O relator proferiu decisão monocrática, assim ementada:

CONFLITO DE COMPETÊNCIA. INCIDENTE SUSCITADO POR TRIBUNAL DE JUSTIÇA EM FACE DO SUPERIOR TRIBUNAL DE JUSTIÇA. IMPOSSIBILIDADE. CONFLITO DE COMPETÊNCIA NÃO CONHECIDO.

- Não se revela processualmente possível a instauração de conflito de competência entre o Superior Tribunal de Justiça, de um lado, e os Tribunais de Justiça, de outro, pelo fato - juridicamente relevante - de que o Superior Tribunal de Justiça

5 A conclusão análoga chegam CHINI, Alexandre e ROCHA, Felippe Borring. A Competência para Julgamento da Reclamação em Face das Decisões Proferidas pelas Turmas Recursais dos Juizados Especiais Cíveis. Revista da EMERJ, vol. 19, n. 4, 2017, passim.

6 DIDIER JÚNIOR, Fredie. Editorial 120. Disponível in http://www.frediedidier.com.br/editorial/editorial-120/, acesso em $03 / 10 / 2016$. 
qualifica-se, constitucionalmente, como instância de superposição em relação a tais Cortes judiciárias, exercendo, em face destas, irrecusável competência de derrogação. Precedentes.

A decisão fundou-se no entendimento segundo o qual não pode haver conflito de competência entre o STJ e um TJ pela razão de que àquele cabe rever as decisões proferidas por este. E isso inviabilizaria, dada a superioridade hierárquica, a admissibilidade de conflitos de competência entre esses tribunais. Com todas as vênias, a decisão não enfrentou uma questão relevante: é que o art. 102, I, o, da Constituição da República expressamente prevê a competência originária do STF para julgar conflitos de competência entre o Superior Tribunal de Justiça "e quaisquer tribunais, entre Tribunais Superiores, ou entre estes e qualquer outro tribunal”, a deixar claro que é compatível com o ordenamento constitucional um conflito de competência entre um Tribunal Superior e qualquer outro tribunal, o que, evidentemente, não exclui os tribunais de segunda instância (aliás, não há outros tribunais, além dos de segunda instância, que não sejam Tribunais Superiores). De todo modo, diante da decisão do STF, os Tribunais de Justiça passaram a julgar essas reclamações, e assim se atingiu o atual "estado da arte" sobre a matéria.

O que a prática forense tem demonstrado é que os Tribunais de Justiça viraram uma espécie de terceira instância dos Juizados Especiais. Agora, a parte vencida na Turma Recursal, não tendo à sua disposição o recurso especial, e não havendo questão constitucional que justifique um recurso extraordinário, ajuíza reclamação, a ser julgada por órgão colegiado do Tribunal de Justiça do Estado. Para que se tenha uma ideia, só a Seção Cível do Tribunal de Justiça do Estado do Rio de Janeiro, no ano de 2019, proferiu 222 acórdãos em reclamações dessa espécie. No primeiro semestre de 2020 foram 97 acórdãos (com todas as dificuldades para que esses julgamentos ocorram, diante do isolamento social causado pela pandemia mundial de COVID-19). E na imensa maioria dos casos o resultado foi a extinção do processo sem resolução do mérito por não ser admissível, na hipótese, a reclamação, a qual era manejada como verdadeiro sucedâneo recursal. Veja-se, a título de exemplo, esta ementa:

0041822-66.2020.8.19.0000 - RECLAMACAO

Des(a). JOSÉ CARLOS MALDONADO DE CARVALHO - Julgamento: 30/06/2020 - SEÇÃO CÍVEL

RECLAMAÇÃO. PROCESSUALCIVIL. PRETENSÃO DE REVISÃO DE ACÓRDÃO PROFERIDO PELATERCEIRA TURMA RECURSAL DOS JUIZADOS ESPECIAIS CÍVEIS DESTE ESTADO, QUE NEGOU PROVIMENTO AO RECURSO INOMINADO INTERPOSTO PELO RECLAMANTE. SENTENÇA PROFERIDA PELO 25으 JUIZADO ESPECIAL DA REGIONAL DA PAVUNA, MODIFICADA PELOS EMBARGOS DE DECLARAÇÃO INTERPOSTOS PELA PARTE RÉ, QUE JULGOU IMPROCEDENTE O PLEITO INDENIZATÓRIO PROPOSTO EM FACE DE LIGHT. PRETENSÃO COM FUNDAMENTO APENAS NO REEXAME DE PROVAS. IMPOSSIBILIDADE. ART. 988, INCISOS I A IV, DO CPC. PRECEDENTES DO SUPERIOR TRIBUNAL DE JUSTIÇA E DESTA CORTE ESTADUAL. INDEFERIMENTO DA PETIÇÃO INICIAL.

O que se vê aí é que a parte reclamante, em vez de fundar-se em algum dos permissivos legais previstos no art. 988 do CPC, limitou-se a deduzir pretensão de reexame das provas produzidas no processo original, tratando a reclamação como mais um recurso ordinário. Aliás, isso é tão evidente que, com muita frequência, o reclamante esquece de atribuir valor à causa, já que não se dá conta de que está a elaborar uma nova petição inicial, tratando da reclamação como se recurso fosse.

Muitos outros exemplos poderiam ser trazidos à colação, do TJRJ ou de outros tribunais. É preciso ter claro que a reclamação não é - nem pode ser - um sucedâneo recursal ou um mecanismo destinado a suprir o não cabimento de recurso especial no sistema processual dos Juizados Especiais Cíveis. ${ }^{7}$ E sua admissibilidade - deixando de lado aqui qualquer consideração acerca da competência originária para dela conhecer - deve ficar restrita aos casos previstos no art. 988 do CPC.

$7 \quad$ Neste sentido, expressamente, JAYME, Fernando Gonzaga; LEROY, Guilherme Costa; SILVEIRA, Thamiris D'Lazzari da. Reclamação ao STJ de decisões proferidas pelos Juizados Especiais Cíveis estaduais: quis custodiet ipsos custodes? Revista de Direito GV, v. 12, n. 2. São Paulo, 2016, pág. 480. 


\section{Conclusão}

O sistema de impugnação das decisões judiciais proferidas nos processos que tramitam perante os Juizados Especiais precisa ser imediatamente revisto. É preciso estabelecer de forma expressa o cabimento de recurso (agravo de instrumento) contra as decisões interlocutórias que versam sobre tutela provisória e contra as decisões interlocutórias proferidas em processos de execução e em cumprimento de sentença. Também é preciso regulamentar o cabimento de recurso especial contra os acórdãos das Turmas Recursais (como forma de permitir que também nos processos que tramitam perante os Juizados exerça o STJ seu fundamental papel de uniformizador da jurisprudência nacional), o que depende de Emenda Constitucional. Mas é essencial que, além disso, as partes compreendam que a reclamação não é um recurso ordinário, e que tem um (relevante) papel a cumprir no ordenamento processual. Assoberbar os Tribunais de Justiça com reclamações manifestamente inadmissíveis em nada contribui para a eficiência do sistema judicial. E é dever de todos, especialmente dos advogados (a quem a Constituição da República atribui o relevante status de serem essenciais à administração da Justiça), contribuir para essa eficiência, sem a qual não há verdadeiro acesso à justiça.

\section{Referências}

ABREU, Vinicius Caldas Gama e. Reclamação Constitucional. Dissertação de Mestrado. São Paulo: PUC-SP. 2018.

CHINI, Alexandre e ROCHA, Felippe Borring. A Competência para Julgamento da Reclamação em Face das Decisões Proferidas pelas Turmas Recursais dos Juizados Especiais Cíveis. Revista da EMERJ, vol. 19, n. 4, 2017.

CUNHA, Leonardo Carneiro da. Novo CPC: Reclamação contra decisões em Juizados Especiais Civeis. Revogação da Resolução 12/2009-STJ. Disponível in http://www.leonardocarneirodacunha. com.br/opiniao/opiniao-61-novo-cpc-reclamacao-contra-decisoes-em-juizados-especiais-civeisrevogacao-da-resolucao-122009-stj/, acesso em 03/10/2016.

DIDIER JÚNIOR, Fredie. Editorial 120. Disponível in http://www.frediedidier.com.br/editorial/ editorial-120/, acesso em 03/10/2016.

HARTMANN, Guilherme Kronemberg. Reclamação no Âmbito do Controle da Observância de Precedentes Judiciais Vinculantes. Revista da EMERJ, v. 21, n. 1, 2019.

JAYME, Fernando Gonzaga; LEROY, Guilherme Costa; SILVEIRA, Thamiris D’Lazzari da. Reclamação ao STJ de decisões proferidas pelos Juizados Especiais Cíveis estaduais: quis custodiet ipsos custodes? Revista de Direito GV, v. 12, n. 2. São Paulo, 2016.

STRECK, Lenio Luiz. Comentário ao art. 988. In: STRECK, Lenio Luiz; NUNES, Dierle; CUNHA, Leonardo Carneiro da (org.); FREIRE, Alexandre (coord.). Comentários ao Código de Processo Civil. São Paulo: Saraiva, 2016. 